\title{
Managing Disease-Modifying Therapies and Breakthrough Activity in Multiple Sclerosis Patients During the COVID-19 Pandemic: Toward an Optimized Approach
}

This article was published in the following Dove Press journal:

Therapeutics and Clinical Risk Management

\author{
Sherif M Hamdy' \\ Maged Abdel-Naseer (ID' \\ Hatem S Shehata (D) \\ Amr Hassan (iD) \\ Alaa Elmazny (1) \\ Nevin M Shalaby' \\ Noha T Abokrysha' \\ Nirmeen A Kishk' \\ Mona AF Nada (D) \\ Sandra M Ahmed' \\ Mohamed I Hegazy (D) \\ Doaa Mekkawy' \\ Husam S Mourad (D) \\ Ahmed Abdelalim (D) ${ }^{\prime}$ \\ Thomas Berger $\mathbb{D}^{2}$ \\ 'Neurology Department, Faculty of \\ Medicine, Cairo University, Cairo, Egypt; \\ ${ }^{2}$ Neurology Department, Medical \\ University of Vienna, Vienna, Austria
}

\begin{abstract}
The emergence of the novel coronavirus disease 2019 (COVID-19) pandemic has become a major public health challenge of global concern since December 2019, when the virus was recognized in Wuhan, the capital city of Hubei province in China and epicenter of the COVID-19 epidemic. Given the novelty of COVID-19 and the lack of specific anti-virus therapies, the current management is essentially supportive. There is an absence of consensus on guidelines or treatment strategies for complex disorders such as multiple sclerosis (MS), in which the risk of infections is higher than in the general population. This is due to the overall impairment of the immune system typical of autoimmune diseases, in addition to accumulation of disabilities, and the iatrogenic effect generated by corticosteroids and the recommended disease-modifying therapies (DMTs). DMTs have different modes of action, but all modulate and interfere with the patient's immune response, thereby raising concerns about adverse effects, such as an increased susceptibility to infections. In this review, we analyze the evidence for use of DMTs during the current critical period and ratify an algorithmic approach for management to optimize care between keeping DMTs, with their infection hazards, or coming off them, with the risk of disease activation. We also provide an algorithmic approach to the management of breakthrough activity during the COVID-19 pandemic.
\end{abstract}

Keywords: COVID-19, multiple sclerosis, disease-modifying therapies

\section{Introduction}

The novel coronavirus disease 2019 (COVID-19) pandemic is a world-shattering infection that affects all geographical areas. The current situation is changing rapidly, with increasing numbers of cases arising across more than 200 countries and territories around the world. ${ }^{1}$ The number of confirmed coronavirus patients has grown substantially, with higher day-to-day increases and evidence of sustained transmission in six continents. ${ }^{2}$

The novel coronavirus is a member of the beta group of coronaviruses, which was named by the International Committee on Taxonomy of Viruses (ICTV) as severe acute respiratory syndrome-coronavirus-2 (SARS-CoV-2) and the disease as COVID-19. ${ }^{3}$ Accumulating evidence suggests that a subgroup of patients with severe COVID-19 may have alveolitis cytokine storm syndrome. ${ }^{4}$ Secondary hemophagocytic lymphohistiocytosis (sHLH) is an underrecognized, hyperinflammatory syndrome
Correspondence: Amr Hassan Kasr Al Ainy Faculty of Medicine, Cairo University, P.O.I I553, Cairo, Egypt Tel +201006060809

Email amrhasanneuro@kasralainy.edu.eg 
characterized by a fulminant and fatal hypercytokinemia with multiorgan failure, which is most commonly triggered by viral infections ${ }^{5}$ and characterized by an increase in proinflammatory mediators. ${ }^{6}$

There is a great complexity of host immune defenses against viral infections. Activation of cytotoxic and other $\mathrm{T}$ lymphocytes (cell-mediated immunity) occurs as early as 3-4 days, ${ }^{7}$ then decreases rapidly within 5-10 days of elimination of the virus. In contrast, humoral immunity appears later (after 7 days) and persists for much longer (often for years). ${ }^{8}$

The knowledge that COVID-19 can cause critical illness and death is a particular concern among patients with chronic illnesses, including multiple sclerosis (MS). ${ }^{9}$

\section{COVID-I 9 Infection Risk Stratification in Patients with Multiple Sclerosis}

A3B2 tlsb -0.02w?>Patients with multiple sclerosis (pwMS) seem to be at higher risk of infection compared with the general population, ${ }^{10}$ and constitute a susceptible population for contracting COVID-19 and frequently developing respiratory insufficiency as a result of their reduced muscle strength, bulbar dysfunction and ineffective secretion clearance; ${ }^{11}$ however, not all patients carry the same risk. Nevertheless, COVID-19 risk can be increased by comorbidities, older age and degree of disability. Moreover, many disease-modifying therapies (DMTs) with various modes of action modulate or interfere with the patient's immune response, raising uncertainties about the increased risk of infection. ${ }^{12}$ According to their risk category, patients should be advised about the appropriate mitigation measures, by practicing social distancing for patients with low risk, social stringency for patients with intermediate risk or shielding for patients with high risk (Table 1).

During the current COVID-19 pandemic, pwMS as well as MS specialists are faced with many challenges: (1) concerns about the use of DMTs in MS patients; (2) delay or deferral in DMT dispensing due to logistic difficulties; (3) shortage of available hospital beds; (4) patients' worries about using immunosuppressive/immunomodulatory treatments; (5) absence of blanket recommendations or consensus regarding maintenance therapy and relapse management; and (6) the need for coordinated efforts to raise awareness among patients and medical society about general and specific infection control measures according to World Health Organization (WHO) recommendations.

The present review discusses the general prophylactic measures for pwMS to mitigate the risk of infection, initiation/maintenance of DMTs and acute relapse management, and tries to design strategies for MS management during the current COVID-19 pandemic.

\section{General Infection Risk Mitigation Measures}

PwMS should adopt the recommended general and national public health measures, including frequent handwashing/ sanitation, social distancing and adequate nutrition. ${ }^{13}$ For patients who have interactive audio/video telecommunications facilities, telehealth services, e-visits and virtual checkins are implemented. In the absence of such means, especially in rural settings, phone calls/WhatsApp texting with the MS team should be available for regular follow-up and for answering patients' queries. Public awareness should be raised through social media campaigns to provide essential information and knowledge about COVID-19, and to reinforce key messages to shape patients' behavior to prevent/minimize the spread of infection.

\section{Initiation/Maintenance of DMTs}

The initiation and maintenance of DMTs in pwMS can be very challenging, especially during this critical period. A few DMTs exert immunomodulatory effects with almost no increase in the risk of systemic infections. Other agents used in MS management have immunosuppressive effects with considerable effects on lymphocyte count, trafficking, proliferation, differentiation and function, leading to an increased risk of infections. ${ }^{14}$ Table 2 summarizes the modes of action, doses and routes of administration of currently approved DMTs.

\section{Interferon-Beta (INF- $\beta$ )}

The therapeutic efficacy of INF- $\beta$ in MS is not only related to its immunoregulatory characteristics, but also to its in vivo anti-viral properties, evident by their significant inhibition on the viral replication of human herpesvirus 6 (HHV-6), which was studied as an example of a latent neurotropic virus. ${ }^{15}$

Leukopenia/neutropenia and, to a lesser extent, lymphopenia are among the very rare hematological abnormalities associated with INF- $\beta$ use; thus, they are usually clinically insignificant. ${ }^{16}$ INF- $\beta$ initiation can be 
Table I Stratification of COVID-19 Risk in Multiple Sclerosis Patients

\begin{tabular}{|c|c|c|c|}
\hline Risk Factor & $\begin{array}{l}\text { Low Risk (Social } \\
\text { Distancing) }\end{array}$ & $\begin{array}{l}\text { Intermediate Risk (Social } \\
\text { Stringency) }\end{array}$ & High Risk (Shielding) \\
\hline $\mathrm{Age}^{93-95}$ & $<40$ years & $40-49$ years & $\geq 50$ years \\
\hline $\begin{array}{l}\text { Comorbidities }^{96} \\
\text { (eg, diabetes mellitus, } \\
\text { hypertension, cardiovascular } \\
\text { disease) }\end{array}$ & Absent & One & Two or more \\
\hline Smoking ${ }^{97}$ & Non-smokers & - & Smokers \\
\hline Type of MS ${ }^{10,98}$ & $\begin{array}{l}\text { RRMS on one of the } \\
\text { low-risk medications }\end{array}$ & $\begin{array}{l}\text { RRMS on one of the intermediate- } \\
\text { risk medications }\end{array}$ & SPMS/PPMS (EDSS >4) \\
\hline $\begin{array}{l}\text { Ambulation index } \\
\text { score }^{11,98,99}\end{array}$ & $\begin{array}{l}0-3 \text { (walks } \\
\text { independently) }\end{array}$ & $\begin{array}{l}\text { 4-5 (unilateral support or bilateral } \\
\text { support, walks } 25 \text { feet in } \leq 20 \\
\text { seconds) }\end{array}$ & $\begin{array}{l}6-9 \text { (bilateral support, walks } 25 \text { feet in }>20 \\
\text { seconds or unable to walk } 25 \text { feet, uses } \\
\text { wheelchair on occasions/most of the time or } \\
\text { restricted to it) }\end{array}$ \\
\hline $\begin{array}{l}\text { Bulbar or respiratory } \\
\text { symptoms related to } \mathrm{MS}^{99,100}\end{array}$ & No bulbar symptoms & Bulbar symptoms & Bulbar and respiratory symptoms \\
\hline Pregnancy ${ }^{101}$ & - & Yes & - \\
\hline Obesity ${ }^{102}$ (body mass index) & $\begin{array}{l}\text { Normal or overweight } \\
\left(18.5-29.9 \mathrm{~kg} / \mathrm{m}^{2}\right)\end{array}$ & Obese $\left(30-39.9 \mathrm{~kg} / \mathrm{m}^{2}\right)$ & Morbidly obese $\left(\geq 40 \mathrm{~kg} / \mathrm{m}^{2}\right)$ \\
\hline Disease-modifying therapies ${ }^{99}$ & $\begin{array}{l}\text { Interferons, glatiramer } \\
\text { acetate, natalizumab, } \\
\text { dimethyl fumarate, } \\
\text { teriflunomide }\end{array}$ & $\begin{array}{l}\text { Alemtuzumab or cladribine in the } \\
\text { past } 6 \text { months, fingolimod, } \\
\text { ocrelizumab or rituximab in the } \\
\text { past } 12 \text { months }\end{array}$ & $\begin{array}{l}\text { Alemtuzumab or cladribine in the past } 12 \\
\text { weeks, AHSCT in the past } 12 \text { months, any } \\
\text { other immunosuppressant }\end{array}$ \\
\hline Lymphopenia ${ }^{2,29,93}$ & Grade 0-I & Grade 2 & Grade 3-4 \\
\hline $\begin{array}{l}\text { Visited or living in a high-risk } \\
\text { area for COVID- } 19^{103}\end{array}$ & No & Yes ( $\geq 14$ days) & Yes ( $<14$ days $)$ \\
\hline $\begin{array}{l}\text { Working in a health-care } \\
\text { facility }{ }^{104}\end{array}$ & No & - & Yes \\
\hline
\end{tabular}

Abbreviations: AHSCT, autologous hematopoietic stem cell transplantation; COVID-19, coronavirus disease 2019; EDSS, Expanded Disability Status Scale; MS, multiple sclerosis; PPMS, primary progressive multiple sclerosis; RRMS, relapsing-remitting multiple sclerosis; SPMS, secondary progressive multiple sclerosis.

associated with influenza-like symptoms, including fever, bone aches, headaches and dyspnea, which usually fade away by 3 months. ${ }^{17}$ However, such symptoms may be confused with COVID-19 symptoms, and thus strict risk mitigation including prolonged dose titration and the use of paracetamol is recommended. The use of non-steroidal anti-inflammatory drugs (NSAIDs) is currently controversial as there have been some reports stating that NSAIDs may exacerbate symptoms in COVID-19 patients. $^{18}$

\section{Recommendations}

INF- $\beta$ can be initiated or maintained safely. Dose titration and the use of paracetamol in starters is recommended. Those who redevelop influenza-like symptoms should be checked for COVID-19 and stop INF- $\beta$ until a clear diagnosis is established. Those who are still experiencing injection-related symptoms should report if the symptoms are exaggerated or different from usual.

\section{Glatiramer Acetate}

Glatiramer acetate (GA) is an MS immunomodulating drug which is not associated with an increased systemic risk of infection. ${ }^{19,20}$ Furthermore, GA tends to be beneficial in the Theiler's murine encephalomyelitis virus model by inducing anti-inflammatory immune responses. It neither increases viral loads nor decreases anti-viral immunity. 
Table 2 Summary of Disease-Modifying Therapies Approved for Use in Multiple Sclerosis ${ }^{16,51,105}$

\begin{tabular}{|c|c|c|c|}
\hline & $\begin{array}{l}\text { Route of } \\
\text { Administration }\end{array}$ & Dose & Principal Proposed Mechanism of Action \\
\hline $\begin{array}{l}\text { Interferon } B-I \mathrm{a} \\
\text { Interferon } B-\mathrm{Ib}\end{array}$ & $\begin{array}{l}\text { IM } \\
\text { SC } \\
\text { SC }\end{array}$ & $\begin{array}{l}30 \mu g \text { once per week } \\
22-44 \mu g \quad 3 \text { times per week } \\
0.25 \text { mg every other day }\end{array}$ & $\begin{array}{l}\text { Down-regulation of MHC expression on APCs, decrease } \\
\text { pro-inflammatory cytokines, inhibit T-cell proliferation, } \\
\text { inhibition of leukocyte migration across the BBB }\end{array}$ \\
\hline Glatiramer acetate & SC & $\begin{array}{l}20 \mathrm{mg} \text { once daily or } 40 \mathrm{mg} 3 \text { times per } \\
\text { week }\end{array}$ & $\begin{array}{l}\text { Shifts pro-inflammatory T-helper-I lymphocyte to } \\
\text { regulatory T-helper2 lymphocyte }\end{array}$ \\
\hline Teriflunomide & $\mathrm{PO}$ & 7-I4 mg once daily & $\begin{array}{l}\text { Selective reversible inhibition of dihydroorotate } \\
\text { dehydrogenase, T-cell activation and cytokine production } \\
\text { inhibitor }\end{array}$ \\
\hline Dimethyl fumarate & $\mathrm{PO}$ & $\begin{array}{l}\text { I } 20 \mathrm{mg} \text { bid for I week then } 240 \mathrm{mg} \text { bid } \\
\text { daily }\end{array}$ & $\begin{array}{l}\text { Decreases pro-inflammatory cytokines and } \\
\text { decreases entry of lymphocytes into the CNS (inhibits } \\
\text { expression of adhesion molecules) }\end{array}$ \\
\hline Fingolimod & $\mathrm{PO}$ & $0.5 \mathrm{mg}$ once daily & Lymphocyte sequestration in secondary lymphoid tissues \\
\hline Natalizumab & IV & $300 \mathrm{mg}$ every 4 weeks & $\begin{array}{l}\text { Interaction with } \alpha \text {-integrins preventing lymphocytes from } \\
\text { crossing BBB }\end{array}$ \\
\hline Cladribine & PO & $\begin{array}{l}3.5 \mathrm{mg} / \mathrm{kg} \text { body weight divided into } 2 \\
\text { yearly treatment courses (I-2 tablets/day } \\
\text { over } 4-5 \text { consecutive days) }\end{array}$ & $\begin{array}{l}\text { Cytotoxic effects on B and T lymphocytes through } \\
\text { impairment of DNA synthesis, resulting in long-lasting } \\
\text { depletion of lymphocytes }\end{array}$ \\
\hline $\begin{array}{l}\text { Ocrelizumab (anti- } \\
\text { CD20) }\end{array}$ & IV & $\begin{array}{l}\text { Initially } 300 \mathrm{mg} \text { once repeated after } 2 \\
\text { weeks, then } 600 \mathrm{mg} \text { every } 6 \text { months }\end{array}$ & Anti-CD20 and depletion of B lymphocytes \\
\hline Mitoxantrone & IV & $\begin{array}{l}12 \mathrm{mg} / \mathrm{m}^{2} \mathrm{q} 3 \mathrm{~m} \text { (maximum cumulative dose } \\
140 \mathrm{mg} / \mathrm{m}^{2} \text { ) }\end{array}$ & Inhibits B cells and $T$ cell and macrophage proliferation \\
\hline Alemtuzumab & IV & $\begin{array}{l}12 \mathrm{mg} \text { daily for } 5 \text { days, then I year later } \\
12 \mathrm{mg} \text { daily for } 3 \text { days }\end{array}$ & Anti-CD25 and depletion of lymphocytes \\
\hline
\end{tabular}

Abbreviations: APC, antigen-presenting cell; BBB, blood-brain barrier; bid, twice a day; CNS, central nervous system; DNA, deoxyribonucleic acid; IM, intramuscular; IV, intravenous; $\mu \mathrm{g}$, microgram; mg, milligram; MHC, major histocompatibility complex; PO, per oral; SC, subcutaneous.

\section{Recommendations}

GA can be initiated or maintained safely during the COVID-19 pandemic.

\section{Teriflunomide}

Teriflunomide selectively and reversibly targets activated $\mathrm{T}$ and B lymphocytes inducing a cytostatic effect, thus limiting their contribution to the inflammatory processes of MS pathogenesis without either compromising the adaptive immunity or increasing the incidence of serious infections in long-term follow-up. ${ }^{21-23}$ Accordingly, teriflunomide is not considered an immunosuppres-

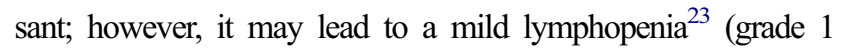
and 2), which usually occurs early in the treatment course and persists for an extended period. Therefore, suspension of teriflunomide treatment with an accelerated elimination procedure should be considered if a patient develops a serious infection. ${ }^{24}$ Mild leukopenia/neutropenia has also been reported. ${ }^{25}$
It is worth mentioning that teriflunomide and its parent compound, leflunomide, have demonstrated both in vitro and in vivo activity against several viruses, including the BK virus, cytomegalovirus, Epstein-Barr virus, herpes simplex virus, Theiler's virus and John Cunningham virus (JCV). ${ }^{26,27}$ Teriflunomide is slowly eliminated from plasma; it takes 8 months to 2 years to reach a plasma concentration less than $0.02 \mathrm{mg} / \mathrm{L}$. Accelerated elimination of teriflunomide should be considered after discontinuation in cases where a serious infection develops. For accelerated elimination, the use of cholestyramine $8 \mathrm{~g}$ administered three times daily or $50 \mathrm{~g}$ of activated powdered charcoal every 12 hours for 11 days is recommended. ${ }^{24}$

\section{Recommendations}

Teriflunomide can be started and maintained during the COVID-19 pandemic in the absence of concurrent infection. Routine laboratory tests should be performed according to the product information. Accelerated elimination 
should be considered if the patient has COVID-19 and teriflunomide is to be discontinued.

\section{Dimethyl Fumarate (DMF)}

The mechanisms of action of DMF include induction of apoptosis of activated $\mathrm{T}$ cells, shift of $\mathrm{CD}^{+} \mathrm{T}$ cells toward a Th2 profile, and reduction of dendritic cell (DC) maturation. DMF has been shown to selectively reduce memory $\mathrm{T}$ cells in MS and decrease the overall B-cell population, in particular mature B cells. ${ }^{28}$ Accordingly, it can potentially induce lymphopenia, which is reported as a worrisome sign in the COVID-19 pandemic. $^{29}$ The frequency of grade 1 lymphopenia was reported to occur in approximately $16.5 \%$ of DMF-treated patients and grade 3 ( 200 to $<500$ cells $/ \mu \mathrm{L}$ ) in $2.4-7 \% .^{30-32}$ Lymphopenia is mainly encountered during the early treatment course, yet it can be severe and may persist even after DMF withdrawal. ${ }^{32}$ PwMS with a lymphocyte count above 800 cells $/ \mathrm{mm}^{3}$ can deal with viral infections reasonably well, provided they are relatively young and have no other comorbidities. Notwithstanding, there is no current evidence of an increased risk of COVID19 infection with DMF. ${ }^{33}$

\section{Recommendations}

DMF can be initiated and maintained during the COVID-19 pandemic provided there is no significant lymphopenia (grade $\geq 3$ ). The usual monitoring guidelines for DMF include complete blood count (CBC) with differential leukocytic and lymphocytic counts before treatment initiation and every 3 months during the first year of treatment, followed by every 6 months thereafter, or as clinically indicated, and it should be discontinued in cases of persistent grade 3 lymphopenia for 6 or more months. ${ }^{34}$ In MS patients with confirmed active COVID-19, interruption of DMF should be considered. ${ }^{33,35}$

\section{Fingolimod}

Fingolimod has been associated with increased risk of infections compared with placebo or IFN- $\beta$ and GA in randomized clinical trials and post-marketing surveillance. ${ }^{36-40}$

Given its effects on lymphocyte trafficking, fingolimod could theoretically increase the risk of infections; yet, definite correlation between reduction of circulating lymphocyte count and the frequency of serious or opportunistic infections was critiqued by some reports, which emphasized that infection was not significantly increased even in patients whose lymphocyte counts had decreased to $<200$ cells/ $\mathrm{mm}^{3.41}$ If the total leukocyte count is $<4000$ and $>2500$ cells $/ \mathrm{mm}^{3}$ and/or the lymphocyte count is $<600$ and $>200$ cells $/ \mathrm{mm}^{3}$, the dose can be reduced to every other day. ${ }^{42}$

According to some pathological findings of pulmonary edema and hyaline membrane formation in COVID-19, the use of immune modulators, together with ventilator support, should be considered for patients with severe symptoms to prevent the development of acute respiratory distress syndrome (ARDS). Currently, there is an ongoing trial that aims to determine the efficacy of fingolimod in the management of COVID- $19 .^{43}$

\section{Recommendations}

Delaying initiation of fingolimod may be considered during the coronavirus pandemic. ${ }^{32}$ For those who are on stable treatment with regular follow-ups, it is recommended to advise patients to closely monitor themselves for any symptoms or signs of infection. In case of any infection, CBC should be performed to exclude significant leukopenia or lymphopenia. If grade 3-4 lymphopenia occurs at any time during the current specific circumstances, other treatment options should be considered. Sudden fingolimod cessation is not recommended owing to the rebound effect that occurs approximately 2-4 months after treatment discontinuation, unless the patient is confirmed to have COVID-19. ${ }^{44,45}$ In MS patients with confirmed active COVID-19, interruption of fingolimod may be considered.

\section{Natalizumab (NTZ)}

NTZ selectively compromises immune surveillance only in the central nervous system by playing a major role in active lymphocyte trafficking across the blood-brain barrier, through binding to the $\alpha_{4}$-subunit of $\alpha_{4} \beta_{1^{-}}$and $\alpha_{4} \beta_{7^{-}}$ integrins expressed on the surface of human leukocytes and vascular cell adhesion molecule- $1 .{ }^{46}$ It is one of the treatment options for patients with aggressive MS or suboptimal response to first line therapies. ${ }^{47}$

Despite the increased risk for progressive multifocal leukoencephalopathy, an opportunistic life-threatening brain infection caused by JCV, the risk of acquiring systemic infections with NTZ is considered relatively low compared to other high-efficacy medications. ${ }^{48}$

NTZ discontinuation may trigger a rebound effect, frequently occurring within 3-6 months of discontinuation; therefore, careful evaluation of risk-benefit should be considered prior to NTZ cessation. ${ }^{49}$ 


\section{Recommendations}

NTZ is currently viewed among the safest high-efficacy therapies to use during the COVID-19 pandemic and could be started and maintained in patients with no current or potential infection, especially in those with aggressive MS. ${ }^{33}$ For patients with active COVID-19 infection, delaying the next infusion should be considered.

\section{Cladribine}

Cladribine causes selective and transient reductions of $\mathrm{CD} 19^{+} \mathrm{B}$ cells and $\mathrm{T}$ cells, followed by reconstitution of adaptive immune function. The hazard of viral infections is significantly higher in the 3-6 months after cladribine intake as the lymphopenia nadir is 9 weeks with up to 12 weeks to recover. ${ }^{50}$

In the integrated analysis of cladribine safety, median absolute lymphocytic count (ALC) reached a nadir of $1.00 \times$ $10^{9}$ cells/ $\mathrm{L}$ at 2 months after the start of treatment during year 1. At the end of year 1 ( 48 weeks), median ALC had increased to $1.21 \times 10^{9}$ cells $/ \mathrm{L}$. During year 2 , median ALC reached a nadir of $0.81 \times 10^{9}$ cells/L at 55 weeks (week 7 in year 2). Median ALC returned to the normal range by 84 weeks (week 36 in year 2). Median ALC returned to the normal range in $75 \%$ of patients by 144 weeks. Grade 3 lymphopenia was experienced by $25 \%$ of patients and grade 4 lymphopenia by $<1 \%$ of patients treated with cladribine tablets. ${ }^{51}$

\section{Recommendations}

Delaying initiation of cladribine should be considered during the coronavirus pandemic. For those who have already started treatment, delaying the second cycle $^{52}$ for 3-6 months or until the risk of coronavirus infection has passed may be considered. For patients with active COVID-19 infection, delaying the second cycle of cladribine should be considered. ${ }^{33}$

\section{Anti-CD20 Therapies}

The first therapeutic anti-CD20 monoclonal antibody $(\mathrm{mAb})$, rituximab (used off-label in MS), is a murinehuman chimera to which many patients develop antibodies and/or experience infusion-related reactions. Ocrelizumab is a second generation recombinant humanized $\mathrm{mAb}$, which selectively binds to CD20-expressing B cells and triggers antibody-dependent cellular cytolysis and complementmediated lysis. Lymphoid stem cells and plasma cells do not express CD20 and therefore are not directly targeted. ${ }^{53}$
B-cell counts are reduced within 2 weeks and remain depleted throughout ongoing treatment. The duration of B-cell depletion was initially estimated to be 6-9 months with rituximab treatment alone ${ }^{53,54}$ and it is now obvious from Swedish experience that rituximab remains effective at controlling disease activity beyond 6 months. ${ }^{54}$ AntiCD20 therapies leave the T-cell compartment of the immune system relatively intact and there have been no severe viral infections in the clinical trial programs. The main viral infection noted with anti-CD20 therapies is herpes zoster or shingles, and even then, these case tend to be mild or moderate. ${ }^{55}$

\section{Recommendations}

Delaying initiation of ocrelizumab and rituximab may be considered during the COVID-19 pandemic. In patients who are stable on treatment, one should consider delaying the next infusion.

\section{Other Immunosuppressant Drugs}

Some other immunosuppressant drugs are used off-label for managing pwMS, especially in low-income countries. A large MS Egyptian cohort, in $2017,{ }^{56}$ showed that about $23.6 \%$ of pwMS were receiving those drugs, including cyclophosphamide (CPM), methotrexate (MTX), azathioprine (AZA) and mitoxantrone, as induction/maintenance therapies. ${ }^{56-59}$

Both CPM and MTX are cytotoxic drugs causing damage to immune cell DNA, thus possessing a potent immunosuppressant effect. AZA acts through inhibition of DNA, RNA and protein synthesis. ${ }^{60-62}$ The main safety concerns of those drugs are lymphopenia, potential risk of infections and hepatotoxicity. ${ }^{63,64}$

Mitoxantrone interacts with the enzyme topoisomerase-2 and causes single- and double-strand breaks by intercalating the DNA through hydrogen bonding. ${ }^{64,65}$ As has been well established for decades, mitoxantrone is a potent immunosuppressive agent targeting proliferating immune cells. It inhibits proliferation of macrophages, B lymphocytes and T lymphocytes. ${ }^{66}$

AZA has a delayed onset of action, with the nadir lymphocyte count being reached at 135 days. Overall, lymphopenia tends to spontaneously resolve with no change in AZA dosing. Lymphopenia is a direct effect of AZA treatment, but lymphopenia-related complications have not been commonly reported. The usual monitoring strategies include weekly monitoring of $\mathrm{CBC}$ and liver enzymes for the first 4 weeks of therapy, or until the maintenance dose is achieved, and then every 3 months. ${ }^{67}$ 


\section{Recommendations}

Clinicians should consider delaying initiation of CPM, MTX and mitoxantrone during the COVID-19 pandemic. Interruption of CPM, MTX and mitoxantrone may be considered. AZA can be started with weekly monitoring of $\mathrm{CBC}$ and transaminases for the first 4 weeks of therapy.

\section{Alemtuzumab (AMZ)}

$\mathrm{AMZ}$ is a humanized anti-CD52 mAb. ${ }^{68,69}$ It induces lysis and apoptosis of cells highly expressing CD52, namely $\mathrm{T}$ and B lymphocytes, ${ }^{70}$ via antibody-dependent cellular cytotoxicity (ADCC) and complement-dependent cytotoxicity, leading to a marked global lymphocyte depletion. ${ }^{71,72}$ AMZ-treated patients exhibit a nearly complete depletion of circulating $\mathrm{CD}^{+}$lymphocytes within a few hours of administration, with a nadir between days 3 and $7 .^{73,74}$ The repopulation of $\mathrm{T}$ lymphocytes starts by month 3 and the return to the lower limit of the normal values occurs by month 6-12; however, this could be delayed for up to 24 months. B cells start to repopulate from 6 weeks onward, return to baseline by 3 months and exceed baseline levels from 6 months. ${ }^{75-78}$

Overall, in key clinical trials, infections were more common in AMZ-treated patients compared to those treated with INFß-1a. ${ }^{73,74,79,80}$ The accumulations of herpes infections during the CARE-MS studies led to the implementation of prophylactic acyclovir treatment $(0-4$ weeks after AMZ infusion). ${ }^{81}$ The treating physician should be vigilant to possible opportunistic infections, particularly in the first few months after AMZ infusion. ${ }^{82}$

$\mathrm{AMZ}$ administration is associated with acute induction of some pro-inflammatory cytokines, such as tumor necrosis factor-alpha (TNF- $\alpha$ ), interleukin-6 (IL-6) and interferon-gamma (INF- $\gamma$ ), which peaks 2-6 hours after infusions and causes the "cytokine-release syndrome". 83

Thus, in the COVID-19 pandemic AMZ carries a significant risk of catching the infection, besides the theoretical potential of aggravating the inflammatory phase of the disease caused by the cytokine storm.

\section{Recommendations}

Clinicians should consider delaying initiation of AMZ during the COVID-19 pandemic. In patients with highly active relapsing-remitting multiple sclerosis (RRMS), the use of an alternative treatment is to be considered, eg, NTZ (or DMF if serum anti-JCV antibodies are positive). If the first or second cycle has already been administered, the patient should adhere to strict social stringency or shielding, or even self-isolation for 3 months or until a CBC demonstrates lymphocytic recovery. If another treatment cycle is due, it could be postponed.

Recommendations for the initiation and maintenance of DMTs in MS patients are summarized in Figure 1.

\section{Management of Relapse}

Patients who present with new or worsening of neurological symptoms and have symptoms suggestive of COVID19 (fever, dry cough, sore throat, headache or bone pains, loss of smell and/or taste) are to be sent for nasopharyngeal and oropharyngeal swab or wash and PCR testing. If the diagnosis of COVID-19 is confirmed, health authorities should be notified according to national requirements. If tests are repeatedly negative, other causes of fever should be searched for and treated accordingly.

If there are no symptoms or signs of any infection, a diagnosis of a true relapse can be made, and standard treatment should be applied. Caution is warranted that pseudorelapse might be followed by a bona fide MS relapse. ${ }^{84}$

A telephone questionnaire can be used to assess the Expanded Disability Status Scale (EDSS) score in cases where patients are unable to attend at their health facility owing to quarantine or curfew. ${ }^{85}$

Relapses that do not or only minimally affect activities of daily living and affect only sensory functional domains are considered mild and do not require steroid treatment under the current pandemic circumstances. Any other relapse, considered moderate or severe, ${ }^{86}$ should receive appropriate treatment.

It is advisable to limit the use of steroids during the COVID-19 pandemic. Pulsed high-dose/continuous oral steroids are immunosuppressive and may, at least theoretically, increase the risk of a COVID-19 viral infection or severity of related symptoms. If steroids are to be given anyway, patients are encouraged to receive standard highdose corticosteroids intravenously at home ${ }^{87}$ with strict self-isolation. Following high-dose corticosteroids, oral tapering is not necessary unless considerable residual symptoms are still encountered. Early clinical trials used steroid tapering after high-dose intravenous corticosteroids to combat potential acute adrenal insufficiency or to maintain the therapeutic effect; however, subsequent studies have shown that this tapering is not necessary after a brief steroid course that does not significantly suppress the hypothalamic-pituitary-adrenal axis, ${ }^{88}$ nor does tapering contribute to recovery. ${ }^{89}$ 


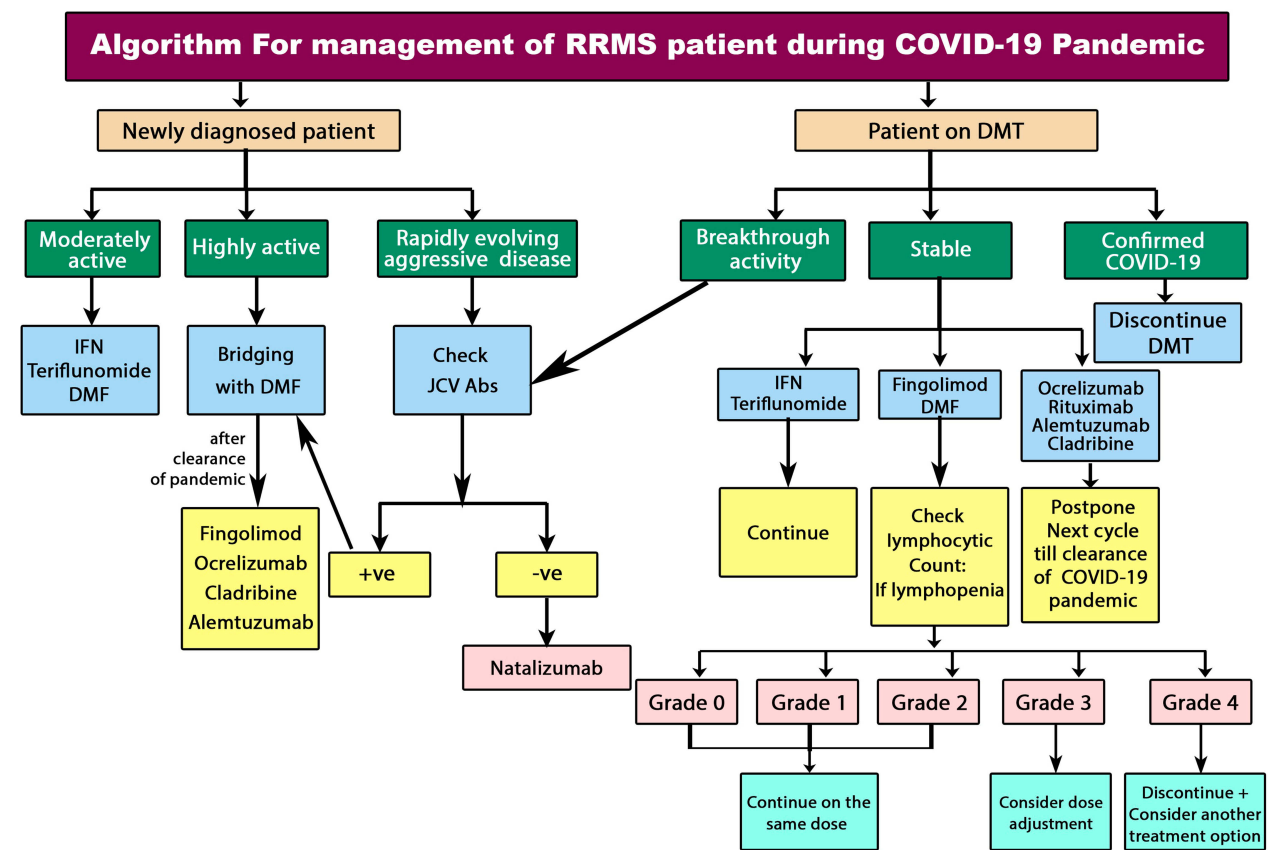

Figure I Algorithm of initiation and maintenance of DMTs in RRMS patients during COVID-19 pandemic. ${ }^{106}$

Abbreviations: COVID-19, coronavirus disease 2019; DMF, dimethyl fumarate; DMT, disease-modifying therapy; INF, interferon; JCV, John Cunningham virus; RRMS, relapsing-remitting multiple sclerosis.

Intravenous immunoglobulin (IVIG) exhibits antiinflammatory effects via inhibition of complementmediated tissue damage and modulation of the cytokine network. It suppresses the production of pro-inflammatory cytokines while increasing the production of antiinflammatory mediators. ${ }^{90}$ Also, it has ian mmunomodulatory influence on different cells of the innate and adaptive immune compartments. ${ }^{91}$

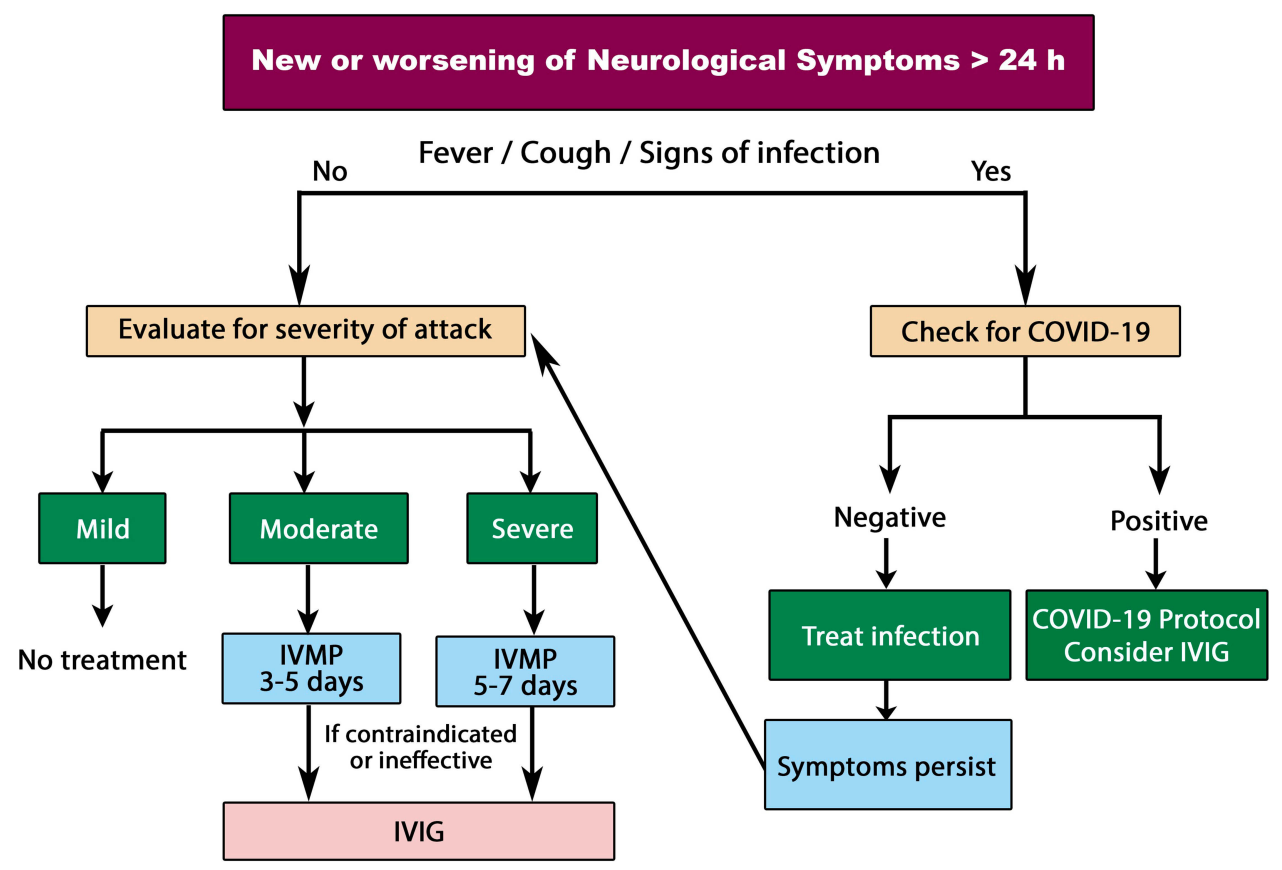

Figure 2 Algorithm of relapse management in RRMS patients during COVID-19 pandemic.

Abbreviations: COVID-19, coronavirus disease 2019; IVIG, intravenous immunoglobulins; IVMP, intravenous methylprednisolone; RRMS, relapsing-remitting multiple sclerosis. 
IVIG therapy has a minimal impact on immune function. ${ }^{92}$ Therefore, IVIG can currently be considered as a good alternative if steroids are contraindicated, poorly tolerated or ineffective, or if hospitalization is impossible.

Plasma exchange may not be a suitable option in the treatment algorithm because of its invasive nature and the need for prolonged hospital stay.

Recommendations for the management of relapse during COVID-19 are summarized in Figure 2.

\section{Summary of Recommendations}

- Before initiating a DMT that may lower immunity, PwMS should remain in quarantine for at least 14 days to exclude potential COVID-19 infection.

- pwMS would not normally need to stop taking their DMT as a result of the threat of the virus.

- Patients on a "treatment-escalation/modification" pathway are not under immediate pressure to change, unless there are other factors (disease activity, JCV positivity, etc).

- Patients on immune reconstitution DMTs can rely on their long-term effect with delaying re-dosing.

- It seems wiser to select a treatment that does not reduce specific immune cells (lymphocytes) (eg, interferons, glatiramer acetate or natalizumab). Medications that reduce lymphocytes over longer intervals (eg, alemtuzumab, cladribine, ocrelizumab and rituximab) or those which may reduce the ability of the immune system to respond to infection (eg, fingolimod, dimethyl fumarate, teriflunomide and siponimod) should carefully be considered with regard to the risks and benefits during the COVID-19 pandemic.

- pwMS who are currently on alemtuzumab, cladribine, ocrelizumab, rituximab, fingolimod, dimethyl fumarate, teriflunomide or siponimod and are living in a community with a COVID-19 outbreak should isolate as much as possible to reduce their risk of infection.

- For patients with active COVID-19 infection, it is mandatory to stop all DMTs. The timing of resuming treatment is not well defined but may depend on serial COVID-19-negative PCR tests within 3-4 weeks of resolution of symptoms.

Although these recommendations can offer guidance toward optimized practice, management of patients with multiple sclerosis during the COVID-19 pandemic is still very challenging given the uncertainty of the current situation and the lack of evidence.

\section{Disclosure}

Thomas Berger has participated in the last 2 years in meetings sponsored by and received honoraria (lectures, advisory boards, consultations) from pharmaceutical companies marketing treatments for multiple sclerosis: Almirall, Biogen, Bionorica, Celgene, MedDay, Merck, Novartis, Roche, Sanofi Aventis/Genzyme, TG Therapeutics and TEVA.His institution has received financial support in the last 2 years by unrestricted research grants (Biogen, Novartis, Sanofi Aventis/Genzyme, Roche, TEVA) and for participation in clinical trials in multiple sclerosis sponsored by Alexion, Biogen, Merck, Novartis, Roche, Sanofi Aventis/Genzyme, TEVA. The authors report no other conflicts of interest in this work.

\section{References}

1. Worldometer. COVID-19 Coronavirus pandemic. Available from: https://www.worldometers.info/coronavirus. Accessed April 3, 2020

2. Zhou F, Yu T, Du R, et al. Clinical course and risk factors for mortality of adult inpatients with COVID-19 in Wuhan, China: a retrospective cohort study. Lancet. 2020;395(10229):1054-1062. doi:10.1016/S0140-6736(20)30566-3

3. Lai CC, Shih TP, Ko WC, Tang HJ, Hsueh PR. Severe acute respiratory syndrome coronavirus 2 (SARS-CoV-2) and coronavirus disease-2019 (COVID-19): the epidemic and the challenges. Int $J$ Antimicrob Agents. 2020;55(3):105924. doi:10.1016/j. ijantimicag.2020.105924

4. Mehta D, Miller C, Arnold DL, et al. Effect of dimethyl fumarate on lymphocytes in RRMS: implications for clinical practice. Neurology. 2019;92(15):e1724-e1738. doi:10.1212/WNL.0000000000007262

5. Ramos-Casals M, Brito-Zerón P, López-Guillermo A, Khamashta MA, Bosch X. Adult haemophagocytic syndrome. Lancet. 2014;383(9927):1503-1516. doi:10.1016/S0140-6736(13) 61048-X

6. Huang C, Wang Y, Li X, et al. Clinical features of patients infected with 2019 novel coronavirus in Wuhan, China. Lancet. 2020;395(10223):497-506. doi:10.1016/S0140-6736(20)30183-5

7. Chaplin DD. Overview of the immune response. J Allergy Clin Immunol. 2010;125(Suppl 2):S3-23. doi:10.1016/j.jaci.2009.12.980

8. Carroll MC. Complement and humoral immunity. Vaccine. 2008;26(Suppl 8):I28-33. doi:10.1016/j.vaccine.2008.11.022

9. Centers for Disease Control and Prevention. Implementation of mitigation strategies for communities with local COVID-19 transmission. Available from: https://www.cdc.gov/coronavirus/ 2019-ncov/downloads/community-mitigation-strategy.pdf. Accessed March 12, 2020

10. Montgomery S, Hillert J, Bahmanyar S. Hospital admission due to infections in multiple sclerosis patients. Eur J Neurol. 2013;20 (8):1153-1160. doi:10.1111/ene.12130

11. Tzelepis GE, McCool FD. Respiratory dysfunction in multiple sclerosis. Respir Med. 2015;109(6):671-679. doi:10.1016/j. rmed.2015.01.018

12. Piehl F. A changing treatment landscape for multiple sclerosis: challenges and opportunities. J Intern Med. 2014;275 (4):364-381. doi:10.1111/joim.12204

13. Ferguson N, Laydon D, Nedjati Gilani G, et al. Report 9: impact of non-pharmaceutical interventions (NPIs) to reduce COVID19 mortality and healthcare demand. 2020. 
14. De Angelis F, John NA, Brownlee WJ. Disease-modifying therapies for multiple sclerosis. BMJ. 2018;363:k4674. doi:10.1136/ bmj.k4674

15. Hong J, Tejada-Simon MV, Rivera VM, Zang YC, Zhang JZ. Anti-viral properties of interferon beta treatment in patients with multiple sclerosis. Mult Scler. 2002;8(3):237-242. doi:10.1191/ $1352458502 \mathrm{~ms} 794 \mathrm{oa}$

16. Torkildsen $\varnothing$, Myhr KM, Bø L. Disease-modifying treatments for multiple sclerosis - a review of approved medications. Eur J Neurol. 2016;23(Suppl 1):18-27. doi:10.1111/ene.12883

17. IFNB Multiple Sclerosis Study Group. Interferon beta-1b is effective in relapsing-remitting multiple sclerosis. I. Clinical results of a multicenter, randomized, double-blind, placebo-controlled trial. The IFNB multiple sclerosis study group. Neurology. 1993;43 (4):655-661. doi:10.1212/WNL.43.4.655

18. Russell B, Moss C, Rigg A, Van Hemelrijck M. COVID-19 and treatment with NSAIDs and corticosteroids: should we be limiting their use in the clinical setting? Ecancermedicalscience. 2020;14:1023. doi:10.3332/ecancer.2020.1023

19. Winkelmann A, Loebermann M, Reisinger EC, Zettl UK. Multiple sclerosis treatment and infectious issues: update 2013. Clin Exp Immunol. 2014;175(3):425-438. doi:10.1111/cei.12226

20. Johnson KP. Risks vs benefits of glatiramer acetate: a changing perspective as new therapies emerge for multiple sclerosis. Ther Clin Risk Manag. 2010;6:153-172. doi:10.2147/TCRM. $\mathrm{S} 6743$

21. Gold R, Wolinsky J. Pathophysiology of multiple sclerosis and the place of teriflunomide. Acta Neurol Scand. 2011;124 (2):75-84. doi:10.1111/j.1600-0404.2010.01444.x

22. Bar-Or A, Pachner A, Menguy-Vacheron F, Kaplan J, Wiendl H. Teriflunomide and its mechanism of action in multiple sclerosis. Drugs. 2014;74(6):659-674. doi:10.1007/s40265-014-0212-x

23. Comi G, Miller AE, Benamor M, Truffinet P, Poole EM, Freedman MS. Characterizing lymphocyte counts and infection rates with long-term teriflunomide treatment: pooled analysis of clinical trials. Mult Scler J. 2019;1352458519851981.

24. Sanofi G. AUBAGIO $14 \mathrm{mg}$ film-coated tablets. Available from: https://www.medicines.org.uk/emc/product/5244/smpc. Accessed October 31, 2019.

25. Oh J, O'Connor PW. An update of teriflunomide for treatment of multiple sclerosis. Ther Clin Risk Manag. 2013;9:177-190. doi:10.2147/TCRM.S30947

26. Zivadinov R, Ramanathan $M$, Hagemeier $J$, et al. Teriflunomide's effect on humoral response to Epstein-Barr virus and development of cortical gray matter pathology in multiple sclerosis. Mult Scler Relat Disord. 2019;36:101388. doi:10.1016/j.msard.2019.101388

27. Able RA, Turner TJ, Chavin J, Mandel M Teriflunomide may modulate viral replication via its impact on host pyrimidine metabolism. Paper presented at: MULTIPLE SCLEROSIS JOURNAL; 2018.

28. Peng H, Guerau-de-Arellano $\mathrm{M}$, Mehta VB, et al. Dimethyl fumarate inhibits dendritic cell maturation via nuclear factor kappaB (NF-kappaB) and extracellular signal-regulated kinase 1 and $2($ ERK1/2) and mitogen stress-activated kinase 1 (MSK1) signaling. J Biol Chem. 2012;287(33):28017-28026. doi:10.1074/ jbc.M112.383380

29. Tan L, Wang Q, Zhang D, et al. Lymphopenia predicts disease severity of COVID-19: a descriptive and predictive study. Signal Transduct Target Ther. 2020;5(1):1-3. doi:10.1038/s41392-0190089-y

30. Mirabella M, Prosperini L, Lucchini M, et al. Safety and efficacy of dimethyl fumarate in multiple sclerosis: an Italian, multicenter, real-world study. CNS Drugs. 2018;32(10):963-970. doi:10.1007/ s40263-018-0543-3
31. Sejbaek T, Nybo M, Petersen T, Illes Z. Real-life persistence and tolerability with dimethyl fumarate. Mult Scler Relat Disord. 2018;24:42-46. doi:10.1016/j.msard.2018.05.007

32. Fox RJ, Chan A, Gold R, et al. Characterizing absolute lymphocyte count profiles in dimethyl fumarate-treated patients with MS: patient management considerations. Neurol Clin Pract. 2016;6(3):220-229. doi:10.1212/CPJ.0000000000000238

33. Alasdair Coles and the MS Advisory Group, in consultation with Dr Ming Lim on behalf of paediatric MS group, Prof Gavin Giovannoni on behalf of MS Academy and Phillip Anderson for the MS Society ABN guidance on the use of disease-modifying therapies in multiple sclerosis in response to the threat of a Coronavirus epidemic. Available from: https://cdn.ymaws. com/www.theabn.org/resource/collection/6750BAE6-4CBC4DDB-A684-116E03BFE634/ABN_Guidance_on_DMTs_for_ MS_and_COVID19.pdf. Accessed March 11, 2020.

34. European Medicines Agency. Updated recommendations to minimise the risk of the rare brain infection PML with Tecfidera. Available from: https://www.ema.europa.eu/en/news/updatedrecommendations-minimise-risk-rare-brain-infection-pmltecfidera. Accessed October 23, 2015.

35. The coronavirus and MS - global advice. Available from: https:// www.msif.org/news/2020/02/10/the-coronavirus-and-ms-whatyou-need-to-know/. Accessed April 6, 2020.

36. Soelberg Sorensen P. Safety concerns and risk management of multiple sclerosis therapies. Acta Neurol Scand. 2017;136 (3):168-186. doi:10.1111/ane.12712

37. Winkelmann A, Loebermann M, Reisinger EC, Hartung H-P, Zettl UK. Disease-modifying therapies and infectious risks in multiple sclerosis. Nat Rev Neurol. 2016;12(4):217. doi:10.1038/ nrneurol.2016.21

38. Grebenciucova E, Pruitt A. Infections in patients receiving multiple sclerosis disease-modifying therapies. Curr Neurol Neurosci Rep. 2017;17(11):88. doi:10.1007/s11910-017-0800-8

39. Cohen JA, Barkhof F, Comi G, et al. Oral fingolimod or intramuscular interferon for relapsing multiple sclerosis. $N$ Engl J Med. 2010;362(5):402-415. doi:10.1056/NEJMoa0907839

40. Gasperini C, Ruggieri S, Mancinelli CR, Pozzilli C. Advances in the treatment of relapsing-remitting multiple sclerosis - critical appraisal of fingolimod. Ther Clin Risk Manag. 2013;9:73-85. doi:10.2147/TCRM.S17426

41. Francis G, Kappos L, O'Connor P, et al. Temporal profile of lymphocyte counts and relationship with infections with fingolimod therapy. Mult Scler. 2014;20(4):471-480. doi:10.1177/ 1352458513500551

42. Longbrake EE, Kantor D, Pawate S, et al. Effectiveness of alternative dose fingolimod for multiple sclerosis. Neurol Clin Pract. 2018;8(2):102-107. doi:10.1212/CPJ.0000000000000434

43. Wang N. Fingolimod in COVID-19. Available from: https://clinical trials.gov/ct2/show/NCT04280588. Accessed February 21, 2020.

44. Havla JB, Pellkofer HL, Meinl I, Gerdes LA, Hohlfeld R, Kümpfel T. Rebound of disease activity after withdrawal of fingolimod (FTY720) treatment. Arch Neurol. 2012;69 (2):262-264. doi:10.1001/archneurol.2011.1057

45. Ghezzi A, Rocca M, Baroncini D, et al. Disease reactivation after fingolimod discontinuation in two multiple sclerosis patients. J Neurol. 2013;260(1):327-329. doi:10.1007/s00415-012-6744-7

46. Engelhardt B, Kappos L. Natalizumab: targeting alpha4-integrins in multiple sclerosis. Neurodegener Dis. 2008;5(1):16-22. doi:10.1159/000109933

47. Rae-Grant A, Day GS, Marrie RA, et al. Practice guideline recommendations summary: disease-modifying therapies for adults with multiple sclerosis: report of the guideline development, dissemination, and implementation subcommittee of the American Academy of Neurology. Neurology. 2018;90 (17):777-788. doi:10.1212/WNL.0000000000005347 
48. Luna G, Alping P, Burman J, et al. Infection risks among patients with multiple sclerosis treated with fingolimod, natalizumab, rituximab, and injectable therapies. JAMA Neurol. 2019;77 (2):184-191.

49. González-Suarez I, Rodríguez de Antonio L, Orviz A, Rodríguez de Antonio L, Orviz A, et al. Catastrophic outcome of patients with a rebound after Natalizumab treatment discontinuation. Brain Behav. 2017;7(4):e00671-e00671. doi:10.1002/brb3.671

50. Giovannoni G. Cladribine to treat relapsing forms of multiple sclerosis. Neurotherapeutics. 2017;14(4):874-887. doi:10.1007/ s13311-017-0573-4

51. Cook S, Leist T, Comi G, et al. Safety of cladribine tablets in the treatment of patients with multiple sclerosis: an integrated analysis. Mult Scler Relat Disord. 2019;29:157-167. doi:10.1016/j.msard.2018.11.021

52. Brownlee W, Bourdette D, Broadley S, Killestein J, Ciccarelli O. Treating multiple sclerosis and neuromyelitis optica spectrum disorder during the COVID-19 pandemic. Neurology. 2020;94 (22):949-952. doi:10.1212/WNL.0000000000009507

53. Kimby E. Tolerability and safety of rituximab (MabThera) Cancer Treat Rev. 2005;31(6):456-473. doi:10.1016/j.ctrv.2005. 05.007

54. Juto A, Fink K, Al Nimer F, Piehl F. Interrupting rituximab treatment in relapsing-remitting multiple sclerosis; no evidence of rebound disease activity. Mult Scler Relat Disord. 2020;37:101468. doi:10.1016/j.msard.2019.101468

55. Gelfand JM, Cree BAC, Hauser SL. Ocrelizumab and other CD20 (+) B-cell-depleting therapies in multiple sclerosis Neurotherapeutics. 2017;14(4):835-841. doi:10.1007/s13311017-0557-4

56. Hamdy SM, Abdel-Naseer M, Shalaby NM, et al. Characteristics and predictors of progression in an Egyptian multiple sclerosis cohort: a multicenter registry study. Neuropsychiatr Dis Treat. 2017;13:1895-1903. doi:10.2147/NDT.S140869

57. Burt RK, Balabanov R, Burman J, et al. Effect of nonmyeloablative hematopoietic stem cell transplantation vs continued disease-modifying therapy on disease progression in patients with relapsing-remitting multiple sclerosis: a randomized clinical trial. JAMA. 2019;321(2):165-174. doi:10.1001/jama.2018.18743

58. Gray O, McDonnell GV, Forbes RB. Methotrexate for multiple sclerosis. Cochrane Database Syst Rev. 2004;(2):Cd003208.

59. Markovic-Plese S, Bielekova B, Kadom N, et al. Longitudinal MRI study: the effects of azathioprine in MS patients refractory to interferon $\beta$-1b. Neurology. 2003;60(11):1849-1851. doi:10.1212/ 01.WNL.0000071218.34009.AF

60. Alberts DS, Einspahr JG, Struck R, et al. Comparative in vitro cytotoxicity of cyclophosphamide, its major active metabolites and the new oxazaphosphorine ASTA Z 7557 (INN mafosfamide). Invest New Drugs. 1984;2(2):141-148. doi:10. 1007/BF00232343

61. Lennard L. TPMT in the treatment of Crohn's disease with azathioprine. Gut. 2002;51(2):143-146. doi:10.1136/gut.51.2.143

62. Pfizer Canada. Product monograph Prmethotrexate injection USP. Available from: https://www.pfizer.ca/sites/default/files/201908/ Methotrexate_Injection_PM_E_224776_08July2019.pdf. Accessed July 82019

63. Orlicka K, Barnes E, Culver EL. Prevention of infection caused by immunosuppressive drugs in gastroenterology. Ther $A d v$ Chronic Dis. 2013;4(4):167-185. doi:10.1177/2040622313485 275

64. Smith IE. Mitoxantrone (novantrone): a review of experimental and early clinical studies. Cancer Treat Rev. 1983;10(2):103-115. doi:10.1016/0305-7372(83)90008-7

65. Durr FE, Wallace RE, Citarella RV. Molecular and biochemical pharmacology of mitoxantrone. Cancer Treat Rev. 1983;10:3-11. doi:10.1016/0305-7372(83)90016-6
66. Fidler JM, DeJoy SQ, Gibbons JJ. Selective immunomodulation by the antineoplastic agent mitoxantrone. I. Suppression of B lymphocyte function. J Immunol. 1986;137(2):727-732.

67. Anstey AV, Wakelin S, Reynolds N. Guidelines for prescribing azathioprine in dermatology. $\mathrm{Br} J$ Dermatol. 2004;151 (6):1123-1132. doi:10.1111/j.1365-2133.2004.06323.x

68. Hale G, Waldermann H. From Laboratory to Clinic: The Story of CAMPATH-1. Clifton. NJ: Humana Press; 2000.

69. Hartung H-P, Aktas O, Boyko AN. Alemtuzumab: a new therapy for active relapsing-remitting multiple sclerosis. Mult Scler J. 2015;21(1):22-34. doi:10.1177/1352458514549398

70. Hu Y, Turner MJ, Shields J, et al. Investigation of the mechanism of action of alemtuzumab in a human CD52 transgenic mouse model. Immunology. 2009;128(2):260-270. doi:10.1111/j.13652567.2009.03115.x

71. Brett S, Baxter G, Cooper H, Johnston J, Tite J, Rapson N. Repopulation of blood lymphocyte sub-populations in rheumatoid arthritis patients treated with the depleting humanized monoclonal antibody, CAMPATH-1H. Immunology. 1996;88(1):13-19. doi:10.1046/j.1365-2567.1996.d01-650.x

72. Buggins AG, Mufti GJ, Salisbury J, et al. Peripheral blood but not tissue dendritic cells express CD52 and are depleted by treatment with alemtuzumab. Blood. 2002;100(5):1715-1720.

73. Coles AJ, Compston D, Selmaj KW, et al. Alemtuzumab vs. interferon beta-1a in early multiple sclerosis. $N$ Engl $\mathrm{J} \mathrm{Med.}$ 2008;359(17):1786-1801.

74. Cohen JA, Coles AJ, Arnold DL, et al. Alemtuzumab versus interferon beta $1 \mathrm{a}$ as first-line treatment for patients with relapsing-remitting multiple sclerosis: a randomised controlled Phase 3 trial. Lancet. 2012;380(9856):1819-1828. doi:10.1016/ S0140-6736(12)61769-3

75. Coles AJ Alemtuzumab treatment of multiple sclerosis. Paper presented at: Seminars in neurology; 2013.

76. Cox AL, Thompson SA, Jones JL, et al. Lymphocyte homeostasis following therapeutic lymphocyte depletion in multiple sclerosis. Eur J Immunol. 2005;35(11):3332-3342. doi:10.1002/eji.2005 35075

77. Zhang X, Tao Y, Chopra M, et al. Differential reconstitution of $T$ cell subsets following immunodepleting treatment with alemtuzumab (anti-CD52 monoclonal antibody) in patients with relapsing-remitting multiple sclerosis. $J$ Immunol. 2013;191 (12):5867-5874. doi:10.4049/jimmunol.1301926

78. Heidt S, Hester J, Shankar S, Friend PJ, Wood K. B cell repopulation after alemtuzumab induction - transient increase in transitional B cells and long-term dominance of naïve B cells. Am $J$ Transplant. 2012;12(7):1784-1792. doi:10.1111/j.16006143.2012.04012.x

79. Coles A, Fox E, Vladic A, et al. Alemtuzumab more effective than interferon $\beta$-1a at 5-year follow-up of CAMMS223 clinical trial. Neurology. 2012;78(14):1069-1078. doi:10.1212/WNL.0b0 $13 \mathrm{e} 31824 \mathrm{e} 8 \mathrm{ee} 7$

80. Coles AJ, Twyman CL, Arnold DL, et al. Alemtuzumab for patients with relapsing multiple sclerosis after disease-modifying therapy: a randomised controlled phase 3 trial. Lancet. 2012;380 (9856):1829-1839. doi:10.1016/S0140-6736(12)61768-1

81. Wray S, Arnold D, Cohen J, Coles A, Fox E, Hartung H Herpes infection risk reduced with acyclovir prophylaxis after alemtuzumab. Paper presented at: Consortium of Multiple Sclerosis Centers Annual Meeting; 2013; Orlando, FL, USA.

82. Brownlee WJ, Chataway J. Opportunistic infections after alemtuzumab: new cases of norcardial infection and cytomegalovirus syndrome. Mult Scler J. 2017;23(6):876-877. doi:10.1177/ 1352458517693440

83. Gallo P, Centonze D, Marrosu MG. Alemtuzumab for multiple sclerosis: the new concept of immunomodulation. Mult Scler Demyelinat Dis. 2017;2(1):7. doi:10.1186/s40893-017-0024-4 
84. Berkovich R. Treatment of acute relapses in multiple sclerosis. Transl Neuroimmunol Mult Scler. 2016;307-326.

85. Lechner-Scott J, Kappos L, Hofman M, et al. Can the expanded disability status scale be assessed by telephone? Mult Scler J. 2003;9(2):154-159. doi:10.1191/1352458503ms884oa

86. Freedman MS, Selchen D, Arnold DL, et al. Treatment optimization in MS: Canadian MS working group updated recommendations. Can J Neurol Sci. 2013;40(3):307-323. doi:10.1017/S03 17167100014244

87. Chataway J, Porter B, Riazi A, et al. Home versus outpatient administration of intravenous steroids for multiple-sclerosis relapses: a randomised controlled trial. Lancet Neurol. 2006;5 (7):565-571. doi:10.1016/S1474-4422(06)70450-1

88. Lević Z, Micić D, Nikolić J, et al. Short-term high dose steroid therapy does not affect the hypothalamic-pituitary-adrenal axis in relapsing multiple sclerosis patients. Clinical assessment by the insulin tolerance test. J Endocrinol Invest. 1996;19(1):30-34. doi:10.1007/BF03347855

89. Perumal J, Caon C, Hreha S, et al. Oral prednisone taper following intravenous steroids fails to improve disability or recovery from relapses in multiple sclerosis. Eur J Neurol. 2008;15 (7):677-680. doi:10.1111/j.1468-1331.2008.02146.x

90. Gilardin L, Bayry J, Kaveri SV. Intravenous immunoglobulin as clinical immune-modulating therapy. CMAJ. 2015;187 (4):257-264. doi:10.1503/cmaj.130375

91. Elovaara I, Kuusisto H, Wu X, Rinta S, Dastidar P, Reipert B. Intravenous immunoglobulins are a therapeutic option in the treatment of multiple sclerosis relapse. Clin Neuropharmacol. 2011;34(2):84-89. doi:10.1097/WNF.0b013e31820a17f3

92. Cao W, Liu X, Bai T, et al.High-dose intravenous immunoglobulin as a therapeutic option for deteriorating patients with Coronavirus disease 2019. Paper presented at: Open Forum Infectious Diseases; 2020.

93. Zhao X, Zhang B, Li P, et al. Incidence, clinical characteristics and prognostic factor of patients with COVID-19: a systematic review and meta-analysis. medRxiv. 2020.

94. Shi Y, Yu X, Zhao H, Wang H, Zhao R, Sheng J. Host susceptibility to severe COVID-19 and establishment of a host risk score: findings of 487 cases outside Wuhan. Crit Care. 2020;24(1):108. doi:10.1186/s13054-020-2833-7
95. Verity R, Okell LC, Dorigatti I, et al. Estimates of the severity of coronavirus disease 2019: a model-based analysis. Lancet Infect Dis. 2020;20(6):669-677. doi:10.1016/S1473-3099(20)30243-7

96. Guan W-J, Liang W-H, Zhao Y, et al. Comorbidity and its impact on 1590 patients with Covid-19 in China: a nationwide analysis. Eur Respir J. 2020;55(5):2000547. doi:10.1183/13993003.005472020

97. Vardavas CI, Nikitara K. COVID-19 and smoking: a systematic review of the evidence. Tob Induc Dis. 2020;18. doi:10.18332/tid/ 119324

98. Nelson RE, Xie Y, DuVall SL, et al. Multiple sclerosis and risk of infection-related hospitalization and death in US veterans. Int J MS Care. 2015;17(5):221-230. doi:10.7224/1537-2073. 2014-035

99. MS and corona care and support. Available from: https://www. mssociety.org.uk/care-and-support/ms-and-coronavirus-care-andsupport. Accessed April 3, 2020.

100. Green JR, Yunusova Y, Kuruvilla MS, et al. Bulbar and speech motor assessment in ALS: challenges and future directions. Amyotroph Lateral Scler Frontotemporal Degener. 2013;14(7-8):494-500. doi:10.3109/21678421.2013.817585

101. Luo Y, Yin K. Management of pregnant women infected with COVID-19. Lancet Infect Dis. 2020;20(5):513-514. doi:10.1016/ S1473-3099(20)30191-2

102. Dietz W, Santos-Burgoa C. Obesity and its Implications for COVID-19 mortality. Obesity. 2020;28(6):1005. doi:10.1002/ oby. 22818

103. Case definition of COVID-19 infection. Available from: https:// www.health.govt.nz/our-work/diseases-and-conditions/covid-19novel-coronavirus/covid-19-novel-coronavirus-information-speci fic-audiences/covid-19-novel-coronavirus-resources-health-profes sionals/case-definition-covid-19-infection. Accessed April 3, 2020.

104. Adams JG, Walls RM. Supporting the health care workforce during the COVID-19 global epidemic. JAMA. 2020;323 (15):1439. doi:10.1001/jama.2020.3972

105. Syed YY. Ocrelizumab: a review in multiple sclerosis. CNS Drugs. 2018;32(9):883-890. doi:10.1007/s40263-018-0568-7

106. Yamout B, Sahraian M, Bohlega S, et al. Consensus recommendations for the diagnosis and treatment of multiple sclerosis: 2019 revisions to the MENACTRIMS guidelines. Mult Scler Relat Disord. 2020;37:101459. doi:10.1016/j.msard.2019.101459

\section{Publish your work in this journal}

Therapeutics and Clinical Risk Management is an international, peerreviewed journal of clinical therapeutics and risk management, focusing on concise rapid reporting of clinical studies in all therapeutic areas, outcomes, safety, and programs for the effective, safe, and sustained use of medicines. This journal is indexed on PubMed Central, CAS,
EMBase, Scopus and the Elsevier Bibliographic databases. The manuscript management system is completely online and includes a very quick and fair peer-review system, which is all easy to use. Visit http://www.dovepress.com/testimonials.php to read real quotes from published authors. 